\title{
OPTIMASI PENEMPATAN RECLOSER UNTUK MEMPERBAIKI KEANDALAN PADA PENYULANG LEMBONGAN MENGGUNAKAN METODE PARTICLE SWARM OPTIMIZATION-FUZZY
}

\author{
Jaime Luis da Costa ${ }^{1}$, Rukmi Sari Hartati ${ }^{2}$, Widyadi Setiawan ${ }^{3}$ \\ Program Studi Teknik Elektro, Fakultas Teknik Universitas Udayana \\ Email: jamesdacosta31@gmail.com ${ }^{1}$, rshartati@unud.ac.id ${ }^{2}$, widyadi@unud.ac.ín ${ }^{3}$
}

\begin{abstract}
Abstrak
Di Bali khususnya Tiga Nusa, kebutuhan tenaga listrik semakin meningkat seiring dengan berkembangnya pembangunan terutama pembangunan resort dan hotel. Dalam penelitian ini diambil contoh kasus tahun 2014 mengenai sistem jaringan Penyulang Lembongan yang masih terpasang beberapa LBS (Load Break Switch) yang digunakan untuk melokalisir gangguan. Oleh karena itu, untuk mengantisipasi gangguan dan meningkatkan keandalan penyulang, salah satu caranya adalah dengan menambahkan penutup balik otomatis (recloser). Penelitian ini bertujuan untuk menentukan lokasi recloser yang optimal pada Penyulang Lembongan dengan menggunakan metode gabungan fuzzy logic dan particle swarm optimization dengan bantuan software MATLAB. Hasil dari penelitian ini diperoleh lokasi terbaik recloser yang berada pada grup 5 yaitu daerah antara LBS SD 3, LBS Celagi Empak, dan LBS Lembongan dengan menambahkan satu recloser. Nilai SAIFI sebesar 1.9471 kali/ pelanggan/ tahun dan nilai SAIDI sebesar 1.4596 jam/ pelanggan/ tahun dimana standar parameter world class service untuk indeks keandalan SAIFI adalah 3 kali/ pelanggan/ tahun dan indeks keandalan SAIDI adalah $2.5 \mathrm{jam} /$ pelanggan/ tahun.
\end{abstract}

Kata Kunci: Keandalan, Recloser, Fuzzy Logic, Particle Swarm Optimization

\begin{abstract}
In Bali, especially at Tiga Nusa, the need for electricity is increasing along with the development of the construction of resorts and hotels. In this study, a sample of cases was taken in 2014 regarding the Lembongan feeder network system which was still installed with several LBS (Load Break Switch) which used to localize interference. Therefore, to anticipate interference and improve the reliability of feeders, one of many ways is to add an automatic back cover (recloser). This study aims to determine the optimal recloser location in the Lembongan feeder by using a combined method of fuzzy logic and particle swarm optimization with the help of MATLAB software. The results of this study obtained the best location of the recloser in group 5, namely the area between LBS SD 3, LBS Celagi Empak, and LBS Lembongan by adding one recloser. The SAIFI value is 1,9471 times / customer / year and the SAIDI value is 1,4596 hours / customer / year where the world class service parameter standard for the SAIFI reliability index is 3 times / customer / year and the SAIDI reliability index is 2,5 hours / customer / year.
\end{abstract}

Keywords: Reability, Recloser, Fuzzy Logic, Particle Swarm Optimization

\section{PENDAHULUAN}

Meningkatnya pariwisata di Bali khususnya di Tiga Nusa (Pulau Nusa Penida, Pulau Nusa Lembongan, Pulau Nusa Ceningan) menyebabkan kebutuhan energi listrik juga semakin meningkat sehingga perlu ditingkatkan keandalannya. Suatu sistem tenaga listrik dikatakan handal apabila nilai System Avarage Interruption Frequency Index (SAIFI) dan System Avarage Interruption Duration Index (SAIDI) kecil atau nilainya mendekati standar World Class Service (WCS) dimana parameter WCS untuk indeks keandalan untuk SAIFI adalah 3 kali/pelanggan/tahun dan untuk SAIDI adalah 
2,5 jam/ pelanggan/ tahun [1]. Tingkat keandalan suatu sistem tenaga listrik juga dapat dilihat dari lamanya pemadaman dan seberapa sering pemadaman itu terjadi [2].

Penyulang Lembongan memakai sistem jaringan distribusi radial, dimana kelemahannya adalah voltage drop cukup besar dan bila terjadi gangguan dekat dengan sumber, maka semua beban saluran akan ikut padam sampai gangguan tersebut dapat teratasi. Berdasarkan data dari PT PLN (Persero) Area Bali Timur nilai indeks keandalan tahun 2014 untuk Penyulang Lembongan memliki nilai SAIFI sebesar 76 kali/ pelanggan/ tahun dan nilai SAIDI sebesar 95,85 jam/ pelanggan/ tahun. Menurut informasi dari PT. PLN Area Bali Timur, gangguan pada Penyulang Lembongan sebagian besar diakibatkan oleh kondisi alam dan hewan disekitar jaringan distribusi. Peralatan pengaman yang terpasang pada penyulang ini terdiri dari beberapa load break switch (LBS) untuk melokalisir gangguan pada saluran [3]. Maka untuk mengantisipasi gangguan dan meningkatkan keandalan jaringan distribusi salah satunya dengan memasang recloser atau penutup balik otomatis.

Menentukan lokasi pemasangan recloser juga tidak pada sembarang titik melainkan harus dilakukan optimasi. Beberapa metode telah digunakan untuk menyelesaikan permasalahan optimasi penempatan recloser, salah satunya adalah penelitian yang dilakukan oleh Lesmana Putra tahun 2015 yaitu menggunakan metode kombinasi logika fuzzy dengan algoritma genetika untuk menentukan letak recloser yang optimal dengan hasil memilih nilai fitness tertinggi dari hasil running program menggunakan MATLAB sebagai posisi recloser yang optimal. Azwar Rachman pada tahun 2013, menggunakan particle swarm optimization (PSO) untuk menganalisis posisi recloser yang paling tepat dengan melakukan pengujian pada nilai SAIFI dan SAIDI. Berdasarkan hasil pengujiannya, nilai SAIFI dan SAIDI pada penyulang bisa tereduksi dengan penempatan recloser yang tepat [3][4].

Penelitian ini akan menentukan lokasi penempatan recloser dengan menggunakan metode yang berbeda dari penelitian sebelumnya yaitu menggunakan metode gabungan particle swarm optimization (PSO) dengan fuzzy logic. Untuk simulasi program menggunakan bantuan software MATLAB. Penelitian ini bertujuan untuk menentukan letak recloser yg optimal dengan berpatokan pada nilai fitness terbaik setelah dioptimasi dan sekaligus memperbaiki nilai SAIFI dan SAIDI pada Penyulang Lembongan.

\section{Sistem Distribusi Tenaga Listrik}

Sistem Distribusi merupakan salah satu dari beberapa komponen dasar sistem tenaga listrik. Sistem distribusi berfungsi untuk menyalurkan energi listrik dari gardu induk ke konsumen. Berdasarkan pola konfigurasi jaringan primer pada suatu sistem distribusi dibagi menjadi beberapa bagian, salah satunya adalah jaringan distribusi pola radial [5]. Penyulang Lembongan menggunakan sistem jaringan distribusi radial karena merupakan jaringan distribusi yang paling sederhana dan saluran ini ditarik dari satu titik sumber dari jaringan itu sendiri dan bercabang pada titik beban yang dilayani.

\subsection{Peralatan pada Sistem Distribusi}

Jaringan distribusi yang baik adalah jaringan yang memiliki peralatan yang cukup lengkap, salah satu yang paling penting adalah peralatan proteksi. Untuk Jaringan distribusi sistem saluran udara, peralatan proteksi dipasangkan diatas tiang-tiang listrik. Peralatan-peralatan proteksi tersebut antara lain: penutup balik otomatis (PBO) atau recloser. Recloser adalah alat pemutus balik otomatis yang bekerja secara otomatis untuk dapat mengamankan sistem dari gangguan hubung singkat. Recloser yang dilengkapi dengan fungsi buka dan tutup secara otomatis sangat berguna untuk menghilangkan gangguan yang berkepanjangan pada sistem yang diakibatkan oleh keadaan gangguan temporer atau arus lebih tiba-tiba (transient over current). Bila recloser mendeteksi adanya arus gangguan di daerah pengamannya maka recloser akan memutuskan arus (membuka kontaktor), kemudian dengan waktu tunda yang ditentukan secara otomatis akan menutup kembali kontak. Jika masih dirasakan adanya gangguan maka recloser akan bekerja 
membuka dan menutup berturut-turut sampai 3 atau 4 kali langsung mengunci [6].

\subsection{Keandalan Sistem Tenaga Listrik.}

Laju kegagalan $(\lambda)$ merupakan nilai atau jumlah dari gangguan dalam suatu interval waktu tertentu. Di dalam menghitung laju kegagalan dari sebuah grup unit, biasanya menggunakan waktu total operasi dari unit daripada waktu kronologinya. Satuan laju kegagalan adalah kegagalan/ tahun. Persamaan laju kegagalan adalah sebagai berikut [1][5]:

$$
\lambda=\frac{\text { jumlah kegagalan }}{\text { total waktu operasi unit }}
$$

Ketidaktersediaan (U) merupakan durasi atau waktu lamanya gangguan dimana sistem tidak dapat menyuplai daya ke pelanggan. Satuan dari ketidaktersediaan (Unavaliability) adalah jam/tahun. Persamaan dari ketidaktersediaan adalah sebagai berikut:

$$
U=\frac{\text { laju kegagalan }}{\text { repair time }}
$$

Untuk menghitung besarnya nilai keandalan biasanya digunakan indeks perkiraan angka keluar (outage) dan waktu perbaikan (repair time) dari masing-masing komponen sesuai dengan SPLN 59:1985. Perkiraan angka keluar (outage) dan waktu perbaikan (repair time) komponen sistem distribusi (trafo distribusi, pemutus tenaga, saklar pemisah) dinyatakan dalam tabel 1 serta tabel 2 untuk data kegagalan saluran udara tegangan menengah [6].

Tabel 1. Data $\lambda$ dan $r$ peralatan menurut SPLN

\begin{tabular}{|l|l|l|}
\hline \multicolumn{1}{|c|}{ Komponen } & \multicolumn{1}{|c|}{$\begin{array}{c}\text { Failure rate } \\
(\boldsymbol{\lambda})\end{array}$} & \multicolumn{1}{|c|}{$\begin{array}{c}\text { Repair Time } \\
(\mathbf{r})\end{array}$} \\
\hline Trafo Dsitribusi & $0,005 /$ unit/tahun & $10 \mathrm{jam}$ \\
\hline Circuit Breaker & $0,004 /$ unit/tahun & $10 \mathrm{jam}$ \\
\hline Sectionalizer & $0,003 /$ unit/tahun & $10 \mathrm{jam}$ \\
\hline
\end{tabular}

Tabel 2. Data $\lambda$ dan $r$ SUTM menurut SPLN

\begin{tabular}{|l|c|}
\hline Sustained Failure Rate $(\lambda / \mathrm{km} /$ tahun) & 0,2 \\
\hline Momentary Failure Rate $(\boldsymbol{\lambda} / \mathrm{km} /$ tahun) & 0,003 \\
\hline
\end{tabular}

\begin{tabular}{|l|c|}
\hline Repair Time (jam) & 3 \\
\hline
\end{tabular}

Keandalan sistem seri merupakan probabilitas dimana semua komponen akan berperan secara serempak atau bersamaan agar sistem tersebut dapat beroperasi sebagaimana mestinya. Persamaar dipakai untuk menghitung laju ke sistem seri adalah sebagai berikut:

$$
\begin{aligned}
& \lambda_{\text {sys }}=\lambda_{1}+\lambda_{2}+\lambda_{3} \\
& U_{s y s}=\lambda_{1} \cdot r_{1}+\lambda_{2} \cdot r_{2}+\lambda_{3} \cdot r_{3} \\
& r_{s y s}=\frac{U_{s y s}}{\lambda_{s y s}}=\frac{\lambda_{1} \cdot r_{1}+\lambda_{2} \cdot r_{2}+\lambda_{3} \cdot r_{3}}{\lambda_{1}+\lambda_{2}+\lambda_{3}}
\end{aligned}
$$

\section{Keterangan:}

$\lambda$ adalah laju kegagalan (failure rate)

$U$ adalah ketidaktersediaan (unavailability)

$r$ adalah waktu perbaikan

Keandalan sistem paralel, suatu system yang disusun secara paralel akan mengalami pemadaman (mati) apabila semua komponen di dalam sistem mengalami kerusakan sebaliknya, jika hanya satu komponen saja yang rusak maka tidak akan menyebabkan sistem mati (padam). Persamaan yang dipakai untuk menghitung laju kegagalan sistem paralel adalah sebagai berikut:

$$
\begin{gathered}
\lambda_{\text {sys }}=\lambda_{1} \cdot \lambda_{2} \cdot \lambda_{3}\left(r_{1}+r_{2}+r_{3}\right) \\
r_{s y s}=\frac{r_{1} \cdot r_{2} \cdot r_{3}}{r_{1}+r_{2}+r_{3}} \\
U_{\text {sys }}=\lambda_{\text {sys. }} \lambda_{\text {sys. }}=\lambda_{1} \cdot \lambda_{2} \cdot \lambda_{3} \cdot r_{1} \cdot r_{2} \cdot r_{3}
\end{gathered}
$$

\subsection{Indeks Keandalan Sistem Jaringan Distribusi}

Keandalan dari pelayanan konsumen dapat dinyatakan dalam beberapa indeks yang biasanya digunakan untuk mengukur keandalan dari suatu sistem. Indeks keandalan yang dipakai dalam penelitian ada 2 yaitu [7]:

- SAIFI (System Average Interruption Frequency Index). Merupakan jumlah rata-rata dari gangguan yang terjadi dalam satu tahun dan ditetapkan ke dalam bentuk persamaan [4]:

$$
S A I F I=\frac{\sum \lambda_{i} \cdot N_{i}}{\sum N_{i}}
$$


- SAIDI (System Average Interruption Duration Index Merupakan waktu kegagalan rata-rata dalam satu tahun untuk tiap pelanggan dan ditetapkan ke dalam bentuk persamaan [4] :

$$
S A I D I=\frac{\sum U_{i} \cdot N_{i}}{\sum N_{i}}
$$

Keterangan :

$\sum \lambda_{i} \cdot N_{i}$ adalah jumlah perkalian antara failure rate dengan jumlah pelanggan komponen $i$

$\sum U_{i} . N_{i}$ adalah jumlah perkalian antara durasi kegagalan dengan jumlah pelanggan komponen $i$.

$\mathrm{Ni} \quad$ adalah jumlah beban pada titik beban $i$ (pelanggan)

$\lambda i$ adalah laju kegagalan

Ui adalah ketidaktersediaan

\subsection{Fuzzy Logic}

Tujuan dari fuzzy logic dalam optimasi penempatan recloser adalah untuk memperkecil daerah yang akan dioptimasi sehingga nantinya akan mempermudah dan menjadi lebih efisien dalam optimasi menggunakan particle swarm optimization. Fuzzy logic digunakan untuk mendapatkan section-section kandidat terbaik yang dipengaruhi oleh jumlah pelanggan pada Penyulang Lembongan. Parameter yang digunakan dalam fuzzy logic ini adalah jumlah pelanggan pada Penyulang Lembongan. Pada kasus penelitian ini menggunakan dua masukan yaitu pelanggan $x$ (masukan 1 ) diasumsikan sebagai jumlah pelanggan yang diselamatkan sebelum pemasangan recloser dan pelanggan $y$ (masukan 2) diasumsikan sebagai pelanggan yang ada sesudah pemasangan recloser. Sedangkan untuk keluaran (nilai kandidat) pada fuzzy logic adalah nilai yang menunjukkan seberapa bagus solusi dari pembagian nilai antara pelanggan $x$ dan pelanggan y apakah bagus atau jelek, yang nantinya hasil dari keluaran akan digunakan untuk menentukan grup mana saja yang akan diseleksi berdasarkan nilai tertinggi dari keluaran (nilai kandidat) yang akan dipakai pada proses optimasi menggunakan particle swarm optimization dengan bantuan
MATLAB software. Metode yang dipakai dalam fuzzy logic ini adalah metode mamdani. Proses kerja fuzzy logic untuk mendapatkan section-section kandidat terbaik ada beberapa tahapan operasional yaitu [8]:

- Fuzzyfikasi

Fungsi dari proses fuzzyfikasi adalah untuk mengubah suatu input (masukan) dari bentuk tegas (crisp) menjadi fuzzy (variabel linguistik) yang biasanya disajikan dalam bentuk himpunanhimpunan fuzzy dengan suatu fungsi keanggotaannya masing-masing.

- Mesin Inferensi Adalah proses implikasi dalam menalar nilai masukan guna penentuan nilai keluar sebagai bentuk pengambil keputusan. Salah satu proses implikasi dalam menalar adalah model penalaran maxmin. Dalam metode mamdani, aplikasi fungsi implikasi menggunakan fungsi MIN dan komposisi antar-rule menggunakan fungsi MAX (menghasilkan himpunan fuzzy baru)

- Basis Pengetahuan Fuzzy

Merupakan kumpulan rule-rule fuzzy dalam bentuk pernyataan IF... THEN

- Defuzzyfikasi

Fungsi dari defuzzyfikasi adalah untuk mengubah keluaran fuzzy yang diperoleh dari mesin inferensi menjadi nilai tegas (crisp) menggunakan fungsi keanggotaan yang sesuai dengan saat dilakukan fuzzyfikasi. Pada metode mamdani, untuk mendapatkan nilai tersebut menggunakan metode centroid atau mencari bobot nilai kurva daerah fuzzy (center of gravity) dengan persamaan matematis seperti berikut:

$$
z=\frac{\int_{a}^{b} x \mu_{A}(x) d x}{\int_{a}^{b} \mu_{A}(x) d x}
$$

Keterangan:

$z$ adalah nilai defuzzyfikasi

$x$ adalah anggota himpunan fuzzy $A$

$\mu_{\text {A ( } x)}$ adalah derajat keanggotaan suatu elemen $x$ dalam suatu himpunan $A$

\subsection{Particle Swarm Optimization}

Tujuan dari particle swarm optimization pada penelitian ini adalah untuk menentukan 
penempatan recloser yang tepat dalam melokalisisr gangguan pada Penyulang Lembongan berdasarkan pada nilai fitness terbaik serta mencari nilai SAIFI dan SAIDI menggunakan bantuan MATLAB software. Berikut merupakan proses langkah kerja dari particle swarm optimization [9]:

1. Menentukan ukuran swarm (populasi), nilai awal, dan kecepatan partikel secara random.

2. Mengevaluasi nilai fungsi tujuan pada setiap partikel

3. Menentukan nilai Pbest (posisi terbaik dari partikel) dan Gbest (posisi terbaik global dari keseluruhan kumpulan partikel)

4. Menghitung kecepatan baru pada iterasi selanjutnya dengan menggunakan persamaan [10]:

$V_{i}^{k+1}=\theta_{k} V_{i}^{k}+c_{1} r_{1}\left(p b e s t_{i}^{k}-X_{i}^{k}\right)+c_{2} r_{2}\left(\right.$ gbest $\left._{i}^{k}-X_{i}^{k}\right)$

Keterangan:

$V_{i}^{k}$ adalah kecepatan partikel i pada iterasi ke $\mathrm{k}$

$\theta_{k}$ adalah bobot inersia (inertia weight)

$r_{1}, r_{2}$ adalah bilangan random berdistribusi uniform antara 0-1

$c_{1}, c_{2}$ adalah bilangan konstan positif $X_{i}^{k}$ adalah posisi partikel i pada iterasi k.

5. Menentukan posisi partikel baru pada iterasi selanjutnya dengan persamaan [10]:

$$
x_{i d}^{k+1}=x_{i d}^{k}+v_{i d}^{k+1}
$$

6. Mengupdate nilai Pbest dan Gbest

7. Melakukan pengecekan apakah solusi sudah optimal atau belum. Juka sudah mendapatkan hasil yang optimal, maka proses algoritma akan berhenti, tetapi jika hasil yang didapat belum optimal maka proses akan diulangi kembali ke langkah nomor 4.

Parameter-parameter algoritma particle swarm optimization yang digunakan dalam optimasi penempatan recloser. Pada kasus penelitian ini, peneliti menentukan beberapa parameter dengan nilai seperti pada tabel 3.

Tabel 3. Parameter Algoritma Particle Swarm Optimization

\begin{tabular}{|c|l|c|}
\hline No & \multicolumn{1}{|c|}{ Parameter } & Nilai \\
\hline 1 & Maximum Iterasi & 600 \\
\hline 2 & Jumlah Partikel pada swarm & 250 \\
\hline 3 & Bobot inersia & 0,5 \\
\hline 4 & $\mathrm{C}_{1}$ dan $\mathrm{C}_{2}$ & 1,5 \\
\hline
\end{tabular}

\begin{tabular}{|c|l|c|}
\hline 5 & Batas Atas Interval $(\mathrm{Ra})$ & 7,5 \\
\hline 6 & Batas Bawah Interval $(\mathrm{Rb})$ & 0 \\
\hline
\end{tabular}

\section{METODE PENELITIAN}

\subsection{Analisis Penelitian}

Pada analisis penelitian ini hal pertama yang dilakukan adalah melakukan pengumpulan semua data dari PT. PLN (Persero) Area Bali Timur. Setelah melakukan pengumpulan baru mulai ke tahap pengolahan data. Pada tahap mengolahan data terdiri dari beberapa bagian yaitu sebagai berikut:

- Membagi Penyulang Lembongan berdasarkan data one line diagram menjadi 8 grup berdasarkan letak LBS (load break switch) guna mempermudah dalam perhitungan keandalannya yaitu untuk mencari nilai failure $\operatorname{rate}(\lambda)$ dan unavailability $(U)$ masing-masing grup.

- Mencari nilai failure rate $(\lambda)$, waktu keluaran $(r)$, dan unavailability $(\mathrm{U})$ load point masing-masing grup dengan menggunakan perhitungan section technique method.

- Mencari nilai SAIFI dan SAIDI Penyulang Lembongan.

- Inisialisasi nilai keanggotaan jumlah pelanggan $x$ dan pelanggan $y$ pada fuzzy logic berdasarkan data jumlah pelanggan yang ada pada Penyulang Lembongan.

- Mencari nilai kandidat (output) terbaik berdasarkan proses kerja fuzzy logic menggunakan bantuan MATLAB software untuk mendapatkan sectionsection kandidat nilai terbaik atau nilai kandidatnya besar yang nantinya akan diseleksi untuk proses optimasi menggunakan particle swarm optimization.

- Inisialisasi awal populasi (swarm) untuk membangkitkan nilai posisi $(X)$ dan kecepatan (V) partikel (individu) awal secara acak.

- Dekode Individu (partikel)

- Evaluasi Individu (partikel) didapat dari nilai hasi dekode individu yang nantinya akan digunakan untuk mencari nilai SAIFI dan SAIDI. 
- Update kecepatan dan posisi baru bertujuan untuk mencari solusi baru berdasarkan kecepatan individu sebelumnya.

- Melakukan pengecekan apakah solusi sudah optimal atau belum dengan berpatokan pada nilai SAIDI dan SAIFI serta nilai fitness terbaik (besar).

\section{HASIL DAN PEMBAHASAN}

\subsection{Sistem Jaringan Distribusi pada Penyulang Lembongan.}

Sistem jaringan distribusi pada Penyulang Lembongan merupakan sistem radial dengan panjang saluran utama penyulang yaitu $21.770 \mathrm{~km}$. Penyulang Lembongan juga memiliki 50 buah trafo distribusi dengan total besar daya terpasang mencapai 6,110 kVA serta total jumlah pelanggan pada penyulang ini mencapai 4,877 pelanggan.

Berdasarkan data-data yang diperoleh dari PT PLN (Persero) Area Bali Timur pada tahun 2014 tercatat Penyulang Lembongan mengalami pemadaman sebanyak 76 kali/ pelanggan/ tahun dengan total lama

\subsection{Fuzzy Logic}

pemadaman sebesar $95.85 \mathrm{jam} /$ pelanggan/ tahun. (PLN Distribusi Area Bali Timur).

Perhitungan nilai SAIDI dan SAIFI Penyulang Lembongan mrnggunakan metode section technique, hal pertama yang perlu dilakukan adalah menghitung nilai failure rate $(\lambda)$ dan nilai unavailability $(U)$ yang sudah dibagi berdasarkan LBS menjadi 8 grup. Langkah selanjutnya yaitu menghitung load point failure rate $(\lambda)$ dan unavailability $(U)$ masing-masing grup yang nantinya total keseluruhan grup akan dikalikan dengan jumlah pelanggan. Gambar pembagian grup berdasarkan letak LBS dapat dilihat pada one line diagram berikut:
Proses optimasi fuzzy logic pada penelitian ini menggunakan metode mamdani yang bertujuan untuk memperkecil area yang akan dioptimasi dengan membagi daerah

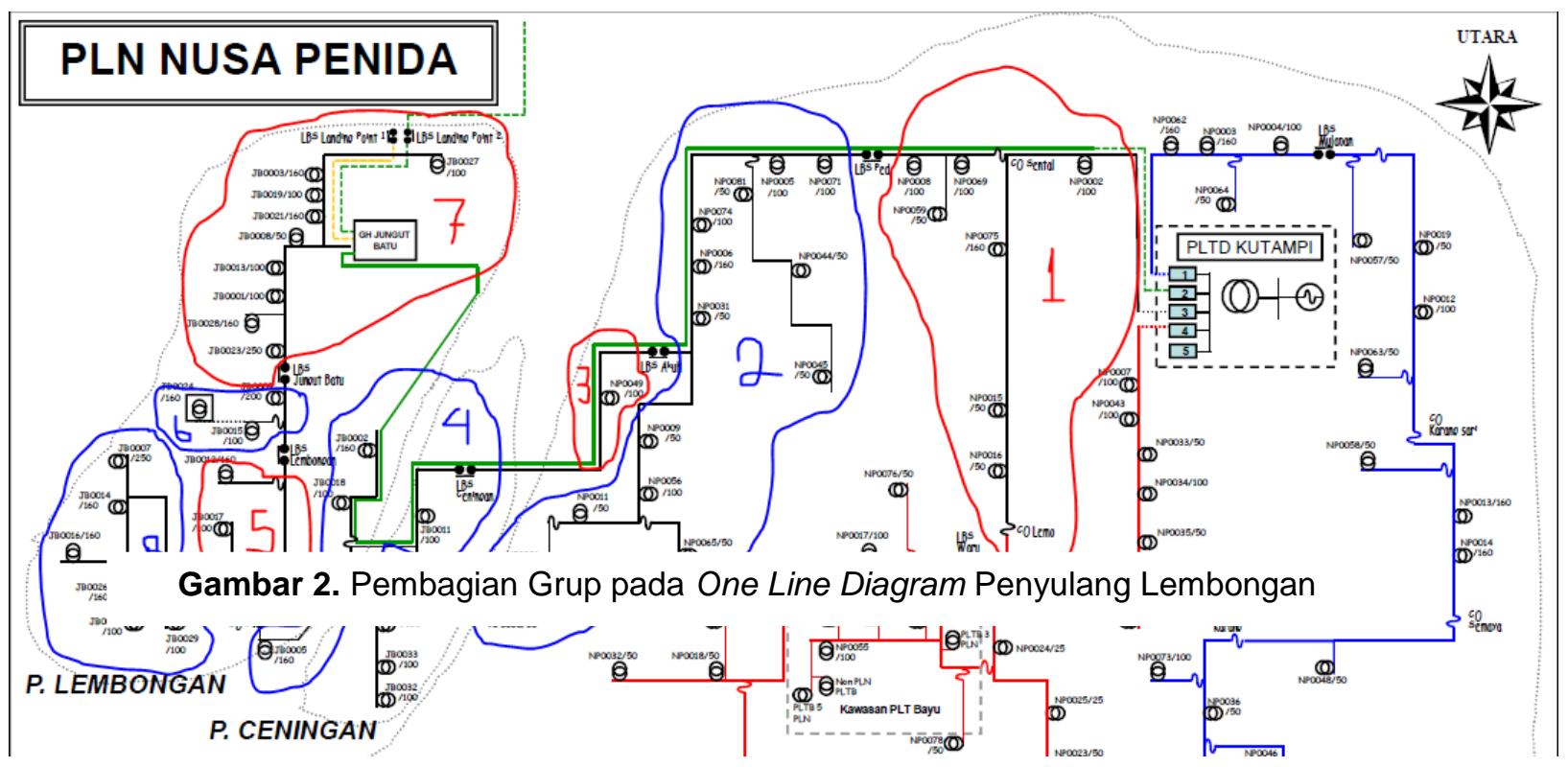


pada Penyulang Lembongan mejadi 8 grup berdasarkan letak LBS (load break switch).

Untuk mendapatkan section-section terbaik (grup yang diseleksi) harus melalui beberapa tahap yaitu sebagai berkut:

- Fuzzyfikasi

Proses fuzzyfikasi menggunakan dua masukan yaitu pelanggan $x$ (masukan 1 ) diasumsikan sebagai jumlah pelanggan yang diselamatkan sebelum pemasangan recloser dan pelanggan y (masukan 2) diasumsikan sebagai pelanggan yang ada sesudah pemasangan recloser. Sedangkan pada keluaran (nilai kandidat) adalah nilai yang menunjukkan seberapa bagus solusi dari pembagian nilai antara pelanggan $x$ dan pelanggan $y$ apakah bagus atau tidak.

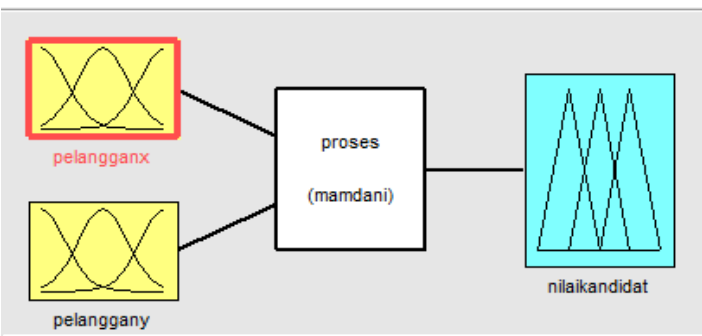

Gambar 3. Pemodelan fuzzy pada MATLAB pada FIS Editor

- Fungsi keanggotaan (membership function) digunakan untuk menentukan batasan (range) pada variabel dan menentukan nilai parameter input dan output pada setiap variabel. kurva yang dipakai pada membership function adalah kurva linier naik, kurva linier turun, dan kurva segitiga. Untuk nilai batasan dan parameter masing-masing variabel dapat dilihat pada gambar 4, 5, dan 6 .

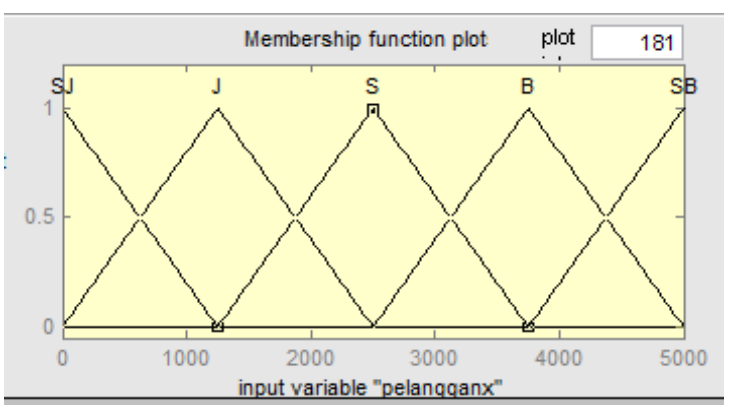

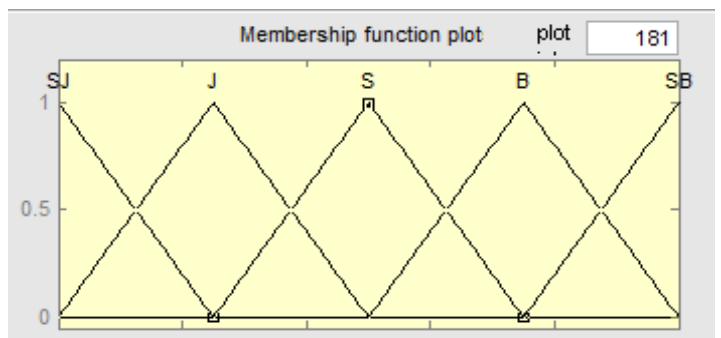

Gambar 4. Fungsi keanggotaan variabel

Gambar 4. Fungsi keanggotaan variabel pelanggan y

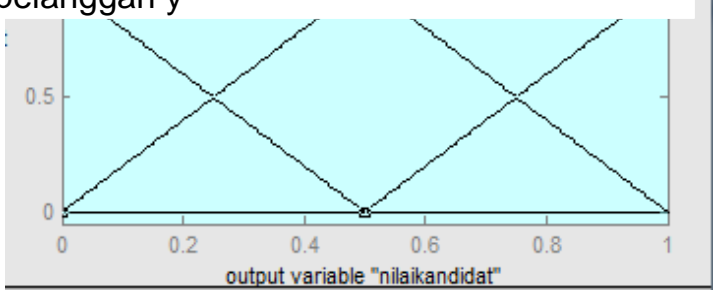

Gambar 6. Fungsi keanggotaan variabel nilai kandidat

- Aplikasi Fungsi Implikasi

Pada metode mamdani, setelah diperoleh variabel masukan dan keluaran, langkah selanjutnya adalah menentukan aplikasi fungsi implikasi, bentuk umum fungsi implikasi yang biasa digunakan adalah If...Then. Berikut merupakan respon masukan pelanggan $x$ dan pelanggan y pada mesin inferensi dapat dilihat pada tabel 4.

Tabel 4. Rule pada Mesin Inferensi

\begin{tabular}{|c|c|c|c|c|c|}
\hline Pelangganx & SB & B & s & J & SJ \\
\hline SB & & & & & \\
\hline B & j & j & j & j & j \\
\hline S & j & s & s & s & j \\
\hline J & j & s & b & s & j \\
\hline SJ & j & s & s & s & j \\
\hline & j & j & j & j & j \\
\hline
\end{tabular}

Keterangan:
$\mathrm{SB}=$ Sangat Banyak $\mathrm{b}=$ Bagus
$\mathrm{B}$ = Bannyak
$\mathrm{S}=$ Sedang
$\mathrm{S}$ = Sedang
$\mathrm{j}=$ jelek
$\mathrm{J}=$ Jarang
SJ = Sangat Jarang 
1. If (pelangganx is S) and (pelanggany is S) then (nilakandidat is b) (1) 2. If (pelanggan $x$ is B) and (pelanggany is B) then (nilaikandidat is $\mathrm{S}$ ) (1) 3. If (pelangganx is B) and (pelanggany is S) then (nilaklandidat is S) (1) 4. If (pelanggan $x$ is $B$ ) and (pelanggany is $\mathrm{J}$ ) then (nilaikandidat is $\mathrm{S}$ ) (1) 5. If (pelangganx is S) and (pelanggany is B) then (nilaikandidat is $\mathrm{S}$ ) (1) 6. If (pelanggan $x$ is S) and (pelanggany is $\mathrm{J}$ ) then (nilaikandidat is $\mathrm{S}$ ) (1) 7. If (pelanggan $\mathrm{x}$ is $\mathrm{J}$ ) and (pelanggany is B) then (nilaikandidat is $\mathrm{s}$ ) (1) 8. If (pelanggan $\mathrm{x}$ is $\mathrm{J}$ ) and (pelanggany is $\mathrm{S}$ ) then (nilaikandidat is $\mathrm{S}$ ) (1) 9. If (pelangganx is $\mathrm{J}$ ) and (pelanggany is $\mathrm{J}$ ) then (nilaikandidat is s) (1) 10. If (pelangganx is SB) and (pelanggany is SB) then (nilaikandidat is i) (1) 11. If (pelangganx is SB) and (pelanggany is B) then (nilaikandidat is j) (1) 12. If (pelangganx is SB) and (pelanggany is S) then (nlaikandidat is $i$ ) (1) 13. If (pelangganx is SB) and (pelanggany is $\mathrm{J}$ ) then (nilaikandidat is j) (1) 14. If (pelangganx is SB) and (pelanggany is SJ) then (nilaikandidat is i) (1) 15. If (pelangganx is SJ) and (pelanggany is SJ) then (nilaikandidat is j) (1) 16. If (pelanggan $x$ is $S J$ ) and (pelanggany is $\mathrm{J}$ ) then (nilaikandidat is $\mathrm{j}$ ) (1) 17. If (pelangganx is $\mathrm{SJ}$ ) and (pelanggany is $\mathrm{S}$ ) then (nilaikandidat is $\mathrm{j}$ ) (1) 18. If (pelangganx is SJ) and (pelanggany is B) then (nilaikandidat is i) (1) 19. If (pelangganx is SJ) and (pelanggany is SB) then (nilak andidat is j) (1) 20. If (pelangganx is $B$ ) and (pelanggany is SB) then (nilaikandidat is $j$ ) (1) 21. If (pelanggan $x$ is $B$ ) and (pelanggany is $S J$ ) then (nilaikandidat is i) (1) 22. If (pelangganx is S) and (pelanggany is SB) then (nilaikandidat is i) (1) 23. If (pelanggan $x$ is $\mathrm{S}$ ) and (pelanggany is $\mathrm{SJ}$ ) then (nilaikandidat is $\mathrm{j}$ ) (1) 24. If (pelangganx is $\mathrm{J}$ ) and (pelanggany is $\mathrm{SJ}$ ) then (nilaikandidat is i) (1) 25. If (pelanggan $x$ is $\mathrm{J}$ ) and (pelanggany is SB) then (nilaikandidat is i) (1)

Gambar 7. Aturan-aturan pada basis pengetahuan fuzzy

\section{- Agregasi Fuzzy}

Setelah proses implikasi selesai, selanjutnya adalah proses penggabungan aturan-aturan fuzzy untuk mendapatkan daerah dari komposisi aturan-aturan yang digunakan. Pada metode mamdani, biasanya menggunakan nilai maksimum atau menggabungkan dari semua aturan yang digunakan.

- Defuzzyfikasi

Proses defuzzifikasi meruupakan tahap akhir dari fuzzy logic yaitu menggunakan metode titik tengah (metode centroid) dengan menggunakan persamaan 2.11. Proses ini peneliti memasukan data jumlah pelanggan $x$ dan pelanggan $y$ pada kolom input maka nilai kandidat (output) akan muncul secara otomatis diatas kurva nilai kandidat seperti pada gambar 8 .

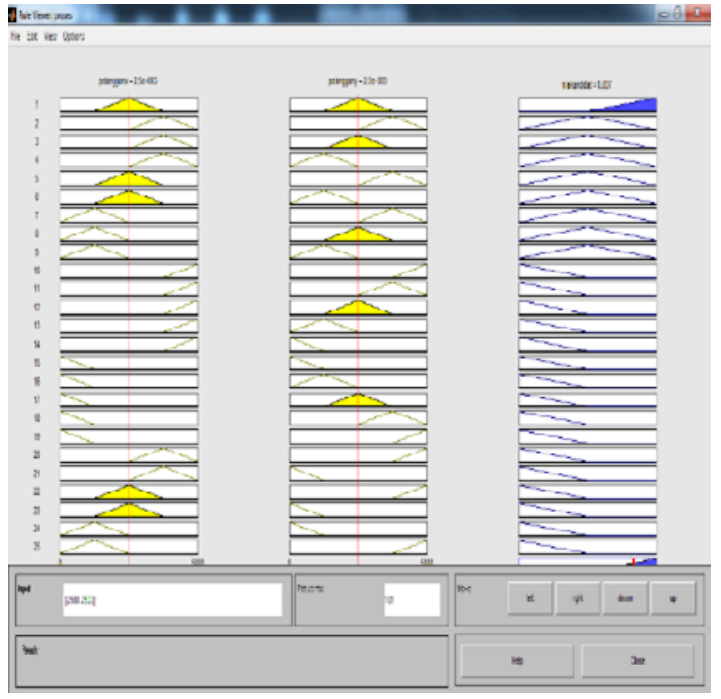

Gambar 8. Tampilan Rule Viewer pada MATLAB Software

Hasil dari proses rule viewer yang nantinya akan diseleksi section-section terbaik yang dilihat dari besarnya nilai kandidat (output) untuk dilanjutkan pada proses optimasi menggunakan particle swarm optimization. Hasil dari proses akhir fuzzy logic dapat dilihat pada tabel 5.

Tabel 5. Hasil Akhir Proses Fuzzy Logic pada MATLAB

\begin{tabular}{|c|c|c|c|c|}
\hline Rangking & $\begin{array}{c}\text { Pelanggan } \\
\mathbf{x}\end{array}$ & $\begin{array}{c}\text { Pelanggan } \\
\mathbf{y}\end{array}$ & $\begin{array}{c}\text { Nilai } \\
\text { kandidat }\end{array}$ & Grup \\
\hline 1 & 2.199 & 2.678 & 0,655 & 4 \\
\hline 2 & 2.110 & 2.767 & 0,623 & 3 \\
\hline 3 & 3.065 & 1.812 & 0,550 & 5 \\
\hline 4 & 3.571 & 1.306 & 0,501 & 6 \\
\hline 5 & 3.808 & 1.069 & 0,494 & 7 \\
\hline 6 & 826 & 4.051 & 0,471 & 2 \\
\hline 7 & 4.711 & 166 & 0,289 & 8 \\
\hline 8 & 0 & 4.877 & 0,165 & 1 \\
\hline
\end{tabular}

Hasil akhir bisa dilihat bahwa grup yang tereliminasi adalah grup 1 dan grup 8 dikarenakan nilai kandidatnya kecil serta perbandingan nilai pelanggan yang kecil. Jadi 
grup yang akan dilanjutkan pada proses optimasi menggunakan particle swarm optimization adalah grup 2 sampai dengan grup 7.

\subsection{PARTICLE SWARM OPTIMIZATION}

Tujuan dari optimasi penenmpatan recloser dengan particle swarm optimization pada MATLAB yaitu untuk menentukan letak recloser yang optimal berdasarkan pada nilai fitness terbaik (besar) dan nilai SAIFI dan SAIDI kecil atau mendekati standar WCS (World Class Service). Pada penelitian ini menggunakan inputan berupa jumlah pelanggan dan nilai load point dari 6 grup yang diseleksi nilai kandidatnya menggunakan fuzzy logic pada Penyulang Lembongan. Adapun parameter-parameter algoritma particle swarm optimization yang dipakai dalam optimasi penempatan recloser yaitu bisa dilihat pada tabel 3 .

Tahap pertama yang dilakukan dalam optimasi penempatan recloser menggunakan particle swarm optimization adalah inisialisasi populasi (swarm). Nilai populasi yang dimasukan sebagai inputan adalah nilai $\lambda$ dan $\mathrm{U}$ load point Penyulang Lembongan. Tujuannya untuk membangkitkan nilai posisi dan kecepatan individu (partikel) awal secara acak. Pada proses inisialisasi dibangkitkan 100 bilangan acak pada masing-masing individu yang nantinya akan ditransformasikan atau didekode menjadi 50 $\lambda$ dan $50 \mathrm{U}$ untuk masing-masing load point. Sedangkan untuk grup, dipilih salah satu grup secara acak yang akan menjadi lokasi recloser. Tahap selanjutnya adalah dekode individu (partikel) yang bertujuan untuk mentransformasikan nilai yang merentang dari 0-1 pada posisi individu kedalam nilai $\lambda$ dan U.nilai rentang yang dimaksud adalah nilai rentang $\mathrm{Ra}$ (batas awal interval) dan $\mathrm{Rb}$ (batas bawah interval) yaitu berkisar antara 0 sampai 0,75 . Setelah melalui tahap dekode individu, selanjutnya ke tahap proses evaluasi individu. Pada proses ini, nilai hasil dekode akan digunakan untuk mencari nilai SAIFI dan SAIDI. Selain itu, data pelanggan Penyulang Lembongan juga akan digunakan sebagai parameter untuk menentukan nilai SAIFI dan SAIDI. Untuk menghitung nilai SAIFI dan SAIDI digunakan 2.9 dan 2.10. setelah memperoleh nilai SAIFI dan SAIDI maka dilanjutkan dengan mencari nilai fitness dengan persamaan:

$$
f(x)=\frac{1}{((\text { SAIFI }+ \text { SAIDI })+\text { BilKecil })}
$$

Bilangan kecil dimasukkan kedalam persamaan fitness agar nilai fitness tidak menjadi $1 / 0$ karena pada penelitian ini diharapkan nilai SAIFI dan SAIDI akan kecil. Tahap selanjutnya yaitu update kecepatan dan update posisi baru dengan menggunakan persamaan 2.12 dan 2.13.

Selama proses optimasi berlangsung atau di running maka akan muncul nilai SAIFI dan SAIDI, fitness terbaik, nilai minimum, dan letak recloser pada display grafik program particle swarm optimization.

Hasil akhir optimasi penempatan recloser menggunakan metode particle swarm optimization untuk mencari letak recloser pada grup yang terdapat pada Penyulang Lembongan beserta display grafik MATLAB

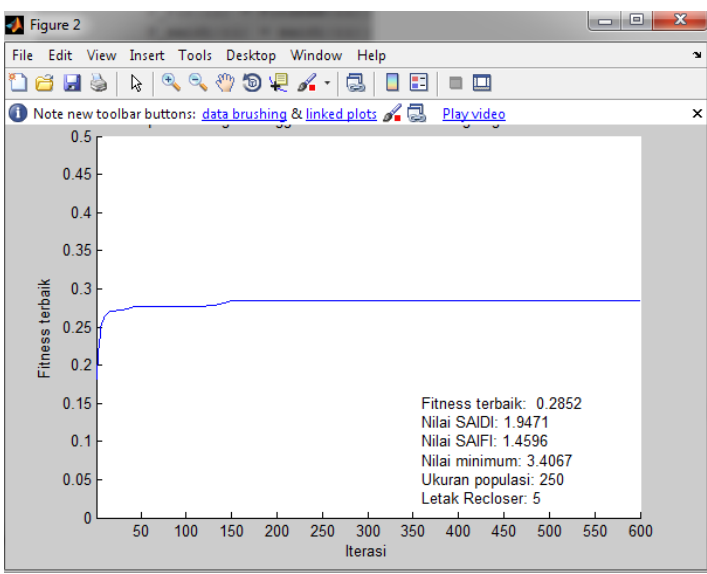

dapat dilihat pada gambar 9 dan tabel 6 .

Gambar 9. Grafik hasil running pada MATLAB Software

Tabel 6. Hasil Akhir Nilai SAIFI dan SAIDI menggunakan metode PSO

\begin{tabular}{|c|c|}
\hline INDEKS & MATLAB (PSO) \\
\hline $\begin{array}{c}\text { SAIFI } \\
\text { (kali/pelanggan/tahun) }\end{array}$ & 1,4596 \\
\hline $\begin{array}{c}\text { SAIDI } \\
\text { (jam/pelanggan/tahun) }\end{array}$ & 1,9471 \\
\hline
\end{tabular}

Berdasarkan tabel 6 bisa dilihat bahwa nilai SAIFI sebesar 1,4596 kali/ pelanggan/ tahun dan nilai SAIDI sebesar 
1,9471 jam/ pelanggan/ tahun. Hal ini sesuai dengan teori bahwa penempatan recloser yang benar atau optimal dapat meningkatkan keandalan sistem tenaga listrik. Dibuktikan dengan mendapat nilai SAIFI dan SAIDI lebih kecil dan sesuai standar parameter world class service (WCS) setelah dioptimasi menggunakan metode particle swarm optimization-fuzzy.

\section{SIMPULAN}

Berdasarkan hasil dari program fuzzy logic dan optimasi menggunakan metode particle swarm optimization pada MATLAB dapat disimpulkan bahwa letak recloser paling optimal berada pada grup 5 dengan nilai SAIDI sebesar 1,9471 jam/ pelanggan/ tahun dan nilai SAIFI sebesar 1,4596 kali/ pelanggan/ tahun. Perbandingan hasil optimasi antara metode gabungan fuzzy logic dengan particle swarm optimization dengan metode sebelumnya yaitu metode algoritma genetika maka dapat disimpulkan bahwa hasil nilai SAIFI dan SAIDI menggunakan metode particle swarm optimization-fuzzy lebih bagus (Lebih kecil) dibandingkan dengan metode algoritma genetika.

\section{DAFTAR PUSTAKA}

[1] Chowdhury. A. dan Koval. D., Power Distribution System Reliability Practical Methods and Applications, New Jersey, IEEE Press, 2009.

[2] Short, Tom, Electric Power Distribution Handbook, Florida, 2004

[3] Putra, I. M. Y. L. 2015. "Optimasi Penempatan Recloser Untuk Meningkatkan Keandalan Sistem Distribusi pada Penyulang Lembongan Menggunakan Metode Kombinasi Logika Fuzzy dengan Algritma Genetika" (tugas akhir), Jimbaran: Universitas Udayana.

[4] Rachman Azwar. 2013. "Optimasi Penempatan Recloser pada Sistem Distribusi Radial Penyulang Kedonganan Gardu Induk Nusa Dua Bali Menggunakan Particle Swarm Optimization" (tugas akhir), Jember: Universitas Jember.

[5] Suhadi. dkk., Teknik Distribusi Tenaga Listrik, Jilid 1, Jakarta, Departemen Pendidikan Nasional, 2008.
[6] Brown.R., Electric Power Distribution Reliability, Second Edition, New York, CRC Press Tylor \& Francis Group, 2009.

[7] PT PLN (Persero), SPLN No. 59, Keandalan pada Sistem Distribusi $20 \mathrm{kV}$ dan $6 \mathrm{kV}$, Jakarta, Departemen Pertambangan dan Energi Perusahaan Umun Listrik Negara, 1985.

[8] Kusumadewi. S., Analisa dan Desain Sistem Fuzzy Menggunakan Toolbox Matlab, Yogyakarta, Graha Ilmu, 2002.

[9] Hsieh, H. I., Lee T. P., Lee, T. S., 2011. A Hybrid Particle Swarm Optimization and Support Vector Regression Model for Financial Time Series Forecasting. International Journal of Business Administration Vol.2, No. 2; May 2011

[10] Kennedy J Ana Eberhart R, "Particle Swarm Optimizer," IEEE International Conference on Neural Network (Perth, Australia), IEEE Service Center Piscataway, NJ, IV, pp1942-1948, 1995. 